\title{
Hardships in Fort Dodge Area
}

\author{
BY A. D. BiCKNeLL ${ }^{\circ}$
}

During the early 70's I was farming in the valley of the Des Moines, twenty-one miles west of Fort Dodge. We had no railroad, and we bought our coal at the mines, seven miles below Fort Dodge, and hauled it home in our wagons.

Generally we took a load of wheat or corn to Fort Dodge, stopping on the way at a sheltered creek bottom, where we fed our team. While the horses were eating we worried down a cold and often frozen lunch, as we danced and stamped our feet to counteract the chill of the luncheon and the weather.

At Fort Dodge we made sale of our grain and delivered it with great haste, because time was as scarce as money, and we still had the mine to make and return before we got supper-in all, for that day, thirty-five miles' drive. It was generally 8 or 9 o'clock at night when we returned to Fort Dodge and sat down to our supper at a cheap hotel. We were spent in nerve and muscle, and so hungry that it is frightful to remember how we did eat. We went to bed as soon as supper was over and to sleep at once. Still-it may seem incredible -but not one ever died at that table or in bed after such a supper.

But during these hardships an inferior coal mine was opened three miles north of Fort Dodge, and it was currently reported that the coal was good, and that clean but plain fare and lodgings could be had at the home of the operator of the mine.

The heavy end of the burden seemed to fall off, and the next time I went to market I drove back to this mine, and got there before supper time, very happy in the thought that I was only eighteen miles from home. My confidence in the fitness of things was a little shaken

- Wintry experiences of early day told by a Humboldt county pioneer. 
when my landlord showed me the stall for my horses, but he explained that most of the farmers who bought his coal brought feed, both for their horses and themselves; that they stood their horses outdoors in the lea of the hill, and that they wrapped their own bodies in a blanket and slept on the floor of a shanty at the side of a roaring free fire. He stated the facts, as I verified them at night.

There was no house at the mine but that of the proprietor, which was a one and half-story shell of inch boards running up and down, with the cracks battened. The roof was built on the same plan-not a warm house for zero weather.

\section{Disappointment at Dining Table}

But a fierce hunger seemed to be gnawing me to pieces, and I hastened in to the supper table. Disappointment has hit me many times, but despair not often. At the table sat half a dozen miners, the full force of the mine. There was not the least doubt that they were miners, for they were black as the coal in the mine, while their hair was straight and their eyes were light, and occasionally the tip of a nose or a spot near the eye showed that the owner had once been white.

They had dropped down to the table just as they came from the mine. They had finished their meal, and were sporting with a loaf of bread, which they threw at each other with great force, shouting at the same time such strange oaths and wild phrases as I had never heard before. My friend, the old man, put on a dignity that was, in fact, normal to him, and requested them to modify the force of their language and the fury of their sport. But they only quit when their strength gave out. They had utterly failed to explode the bread. It came out of the fray still defiant and as sound as a newly cast bomb.

The unwashed miners left the table and loaded their pipes, the hired girl came in, picked the immortal loaf from the floor, laid it on the table and cast a loving smile at one of the boys. He rolled his eyes, showed 
his teeth and smiled back the same queer smile. It seemed a caricature on the tender emotions. I had lost interest in my supper and was greatly enjoying the novel scene, and so was fairly startled when the old man said, "Sit right up, things is a little slim tonight. The boys was a little hungry I see and they haven't left much, but I s'pose you had a good dinner and ain't very hungry." There was nothing on the table but that loaf of bread and mussed-up mess of potato that looked as though it had been beaten in water and poured into the dish. The girl poured some hot water onto the coffee grounds and our coffee was ready.

A tame 'coon crawled out of his corner and insisted on close acquaintance. I was a coward as to 'coons. I remembered one from away back that had measured his teeth in my thumb, and they reached clear through it. Neither the old man or I ventured warfare on the bread. I left the table without eating an ounce, and the unselfish 'coon climbed into my chair and cleaned up my plate.

The old man was genial and full of probable and improbable stories of his strenuous life. Hoping that I might wear myself into a weariness that would let me sleep, I coaxed his limber tongue to run till past midnight. This was out in the "office" where my friends, the farmers, had long since been sleeping and snoring on the bare floor, all dressed and wrapped in a variety of make-shift blankets. Oh, but they were a destitute looking lot!

The old man was both kind and thoughtful. He said that his wife was away, and that as the night was so very cold, probably I had better sleep with him; if not, I had better fetch in one of my horse-blankets, because bedding was a little scarce for such a wintry night. I approved the good taste of his wife, and declined both his bed and the horse-blanket, but spread all my clothes on my own bed, with the overcoat on top to hold the lesser garments in place. I felt sure that I should be asleep in a minute and that I should sleep alone and un- 
disturbed. I was fooled on all points. I had only fairly got settled to business, when, coming up through a great stovepipe hole in the floor at the side of my bed, I heard that old and never ending story-the same I have noticed in all languages. First, a deep bass, monotonous voice, answered by a keen soprano, "te-he-he-he-he"many times repeated. It was the girl of the supper table and her grinning beau.

\section{Visited By A Raccoon}

I lost all hope of sleep and was getting quite comfortable, cheered by the happiness below, and listening to the music of the old man's serene and heavy snore, when-awful moment-I heard a patter of soft feet and the rattle of a chain, and that villainous 'coon pounced onto my bed. I was both confused and terrified. Should I wake the old man? Should I call one of the cooing doves below, or what? Three times I worked Mr. 'Coon down toward my feet and kicked him onto the floor. But each time he returned, growling worse and madder than before. Meanwhile the bed had ceased to be a safe protection against the cold or the 'coon.

In my desperation I reasoned that the parties below could relieve the situation and begin their work again where they left off without great loss or damage, and I called down for help. The young lady was worthy. She explained that "the 'coon won't hurt nobody." But I was so insistent that she finally yielded to my request, came up and chained the 'coon to the bedpost at my feet. I fully realized that the joke was on me, and gave up the battle. As I thanked her for her kindness, the 'coon sprung upon the bed and the girl climbed down the ladder, snorting as she went. After all, I had not done the lovers any harm.

The longest night that ever was came to an end, and when morning dawned, there lay my 'coon peering at me with malicious eyes and a grin on his face that fairly asked me how I liked it. And I liked it first rate.

At my breakfast that morning there was the same bombshell of bread of the supper table and everything 
else was like the night before. I ate nothing, but I drank two cups of vile slop, for it had one virtue-it was hot. I paid a dollar for my entertainment, and was never better satisfied in my life. It was a rare experience, such as cannot now be bought for money.

I faced a blizzardy wind eighteen miles home, and walked all the way in the lea of the wagon, so that-I should not freeze. I have never seen that mine since!

\section{Legislative Repartee}

Both wit and repartee often liven the session of a legislative assembly. Men of rare qualities are included in the membership, who prove positively annoying at times when the more staid and sober-minded are engaged in the dry routine of assembly discussions. One such was Representative Mahlon Head.

During one of these sessions a bill was introduced and considered, having for its object the construction of farm community telephone lines along section lines where there were no roads. Naturally it was somewhat controversial. Considerable lobby work had been done by its sponsors and it finally came to the floor for consideration. It was in charge of a large man from one of the north-eastern Iowa counties who talked in a loud voice and emphasized his thread of argument with a waving of arms.

Representative Head was plainly irked and finally exploded, securing the speaker's recognition for statement under the "personal privilege" rule, exclaiming that he "had no objection personally to these builders of telephone lines stringing their wires all over the state," but did "wish to emphatically protest against their setting up windmills and then going away and leaving them running."

The house resounded in uproarious laughter, which the speaker of the assembly allowed to run its course, while the exponent of the legislation plainly discomfited quickly finished his speech that had seemed to be endless. 
Copyright of Annals of Iowa is the property of State of Iowa, by \& through the State Historical Society of Iowa and its content may not be copied or emailed to multiple sites or posted to a listserv without the copyright holder's express written permission. However, users may print, download, or email articles for individual use. 